\title{
Nickel and copper residues in meat from wild artiodactyls hunted with nickel-plated non-lead rifle bullets
}

\author{
Peter Paulsen $^{1}$ (1) $\cdot$ Manfred Sager ${ }^{2}$
}

Received: 20 February 2017 /Revised: 19 May 2017 / Accepted: 13 June 2017 / Published online: 27 June 2017

(C) The Author(s) 2017. This article is an open access publication

\begin{abstract}
A nickel (Ni)-plated copper-solid bullet type released up to $93 \mu \mathrm{g} \mathrm{Ni} / 10 \mathrm{~g}$ bullet mass when immersed into meat juice for 7 days (to simulate fragments remaining in venison). A non-nickel-plated counterpart of identical construction released no $\mathrm{Ni}$, but up to $250 \mu \mathrm{g}$ copper. During thermal processing of pork cubes with embedded bullets, an average of 2.8 and up to 4.3 (maximum) $\mu \mathrm{g} \mathrm{Ni}$ were released from the Ni-plated bullet to the surrounding meat. Average nickel and copper content in meat samples (taken in 2-3 cm distance from the shot wounds) from 30 roe deer (Capreolus capreolus) and 3 sika deer (Cervus nippon) killed with nickelplated copper bullets did not differ significantly from those in controls (roe deer haunch). Contamination scenarios would $\mathrm{Cu}$ and $\mathrm{Ni}$ contents per portion increase moderately by 20 and $3.3 \mu \mathrm{g}$, respectively. In order to limit alimentary Ni uptake, the technological need for Ni-plating of bullets should be carefully evaluated.
\end{abstract}

Keywords Nickel $\cdot$ Copper, rifle bullets · Venison ·

Consumers' exposure

\section{Introduction}

Based on environmental, animal conservation as well as public health concerns on lead, it is widely accepted that bullet-

Peter Paulsen

peter.paulsen@vetmeduni.ac.at

1 Institute of Meat Hygiene, Meat Technology and Food Science, University of Veterinary Medicine Vienna, 1210 Vienna, Austria

2 Austrian Agency for Health and and Food Safety (AGES), 1220 Vienna, Austria borne deposition of lead in the environment or in venison should be minimized (BfR 2010). "Non-lead" projectiles are available for this purpose (Thomas 2013), and it seems that precision and killing power issues can be or are already solved (Trinogga et al. 2013; Kanstrup et al. 2016). Concurrently, the deformation and/or fragmentation pattern of bullets/shot has been studied in more detail (Gremse et al. 2014). It has been shown that the energy transfer is less dependent of the bullets' materials used, but more on the constructional features and the velocity of the projectile. Also, non-fragmenting bullets can ensure adequate energy transfer to the animal's tissues. From a conservation point of view, non-fragmenting bullets or bullets fragmenting in few large pieces are preferred since raptors are able to avoid the ingestion of larger metallic particles (Nadjafzadeh et al. 2015). Likewise, such bullet types would ensure that contamination of venison by bullet fragments is kept to a minimum. However, it must be borne in mind that even a non-fragmenting projectile will deposit small metal flakes along the wound channel (Felsman et al. 2016), and that deforming bullets might lose larger single fragments during expansion. The review of Thomas et al. (2016) provides a comprehensive overview on all facets of non-lead hunting ammunition.

Currently available non-lead bullets can be conveniently divided in monolithic copper- or copper alloy types, occasionally with nickel coating or aluminium or plastic tip and such with jacket-core construction, e.g. a tin core replacing lead (Irschik et al. 2014; Paulsen et al. 2015a). Deposition of copper along the wound channel and migration of $\mathrm{Cu}$ from embedded bullet fragments during meat storage and preparation have been studied recently (Irschik et al. 2013, 2014; Schuhmann-Irschik et al. 2015; Paulsen et al. 2015a, b), and it was concluded that the amounts released would be of no significance for human health and also not be able to trigger meat spoilage via fat oxidation (Schuhmann-Irschik et al. 
2015; Paulsen et al. 2017). However, it could be shown that lead-free bullets with Ni-plating would release Ni during simulated digestion (Paulsen et al. 2015a) and the question was posed what amounts of $\mathrm{Ni}$ would be released from nickelplated bullets when passing the animal's body or from fragments deposited in edible tissues. To this end, we examined the release of $\mathrm{Ni}$ from plated bullets in two model systems in comparison with a non-nickelled counterpart. In addition, we tested tissue from shot wounds of animals killed by two types of nickel-plated copper-solids. Finally, an estimate of foodborne exposure to $\mathrm{Ni}$ was made.

\section{Materials and methods}

\section{Carcass samples}

Samples were obtained from 33 wild ungulates (30 roe deer (Capreolus capreolus) and 3 sika deer (Cervus nippon)). Animals had been shot by nickel-plated copper-solids with either an open hollow point tip (Kalahari $\AA$, norma $A B$, Amotfors, Sweden; "K"-type) or a hollow tip covered with plastic (RWS HIT®, RUAG Ammotech, Fürth, Germany; "H"-type). Both entry and exit wounds were in the cranialthoracal region. As samples were obtained from regular hunting events, there was a variation as regards calibres, shooting distance and animal weight. In more detail, 20 carcasses with HIT $8 \times 57$ IS shot wounds could be sampled (17 roe deer and 3 sika; carcass weights 7-20 kg; shooting distance 30-150 m with a median of $85 \mathrm{~m}$ ), and 13 roe deer with Kalahari shot wounds (.270 Winchester; .308 Winchester and $7 \times 64$; carcass weights $8.5-20 \mathrm{~kg}$; shooting distance $40-140 \mathrm{~m}$ with a median of $60 \mathrm{~m}$ ).

The shot wound had not been cleaned or trimmed during evisceration. Within $24 \mathrm{~h}$ post-mortem, muscle tissue surrounding entry and exit wounds was taken (radius of $3 \mathrm{~cm}$ from the shot wound). From 17 roe deer carcasses, an additional $25 \mathrm{~g}$ muscle sample (hind leg) was provided (control).

Cutting and mincing of samples was done with ceramic knives (Graefe, Germany) on polypropylene cutting boards, in order to avoid contamination with nickel from stainless steel surfaces. Blood clots and bruised tissues were removed, and only meat in a distance of 2-3 cm from the wound was taken. Such meat was chopped, vacuum packed and stored frozen at $-25^{\circ} \mathrm{C}$ until analysis. Samples were then portioned in $0.5 \mathrm{~g}$ subsamples for analysis. Within one sample, the number of $0.5 \mathrm{~g}$ subsamples varied from 2 to 7 . These subsamples were analysed separately, but the results were averaged in order to represent the sample.

From five roe deer, samples of ruminal content were provided.

\section{Experimental procedure to determine solubility of nickel and copper}

For these experiments, HIT® and its non-nickel-plated counterpart (Barnes TTSX®, Barnes Bullets, Mona, USA, "T"type), both $0.308 \mathrm{in}$. diameter and $10.7 \mathrm{~g}$ weight were used. Bullets were obtained by pulling from live rounds with an inertia hammer. For HIT bullets, the Ni-plating was scraped off from one third of the cylindrical part of the bullet, in order to simulate the abrasion taking place when the bullet passes the barrel rifling.

To estimate the solubility of nickel and copper from bullets in acidic liquids, bullets were placed tip-down in a reagent tube and $5 \mathrm{ml}$ freshly pressed beef juice ( $\mathrm{pH}$ 5.7) were added so that the bullet was completely covered with liquid. Tubes were then stored at $0-2{ }^{\circ} \mathrm{C}$ in the dark for 7 days under static conditions. Then, bullets were removed and copper and nickel concentration in the liquids were determined. For each bullet type, $n=6$ specimens were tested.

In addition, the release of nickel and copper into meat was studied. Pork loin was obtained $24 \mathrm{~h}$ after slaughter and cut into $50 \mathrm{~g}$ cubes. In each cube, a bullet was inserted so that it was fully covered by meat. Meat cubes were vacuum packed and then placed in a water bath set at $+72{ }^{\circ} \mathrm{C}$ and were boiled for $45 \mathrm{~min}$. to $+70{ }^{\circ} \mathrm{C}$ internal temperature. The bag was opened and the meat was allowed to reach room temperature. Subsequently, the meat cube was cut up with a ceramic knife and a 2-mm-thick meat slice around the bullets was removed; meat sticking on the bullet surface was removed with toothpicks. Meat was then chopped and stored at $-20{ }^{\circ} \mathrm{C}$ until analysis. Per bullet type, five meat cubes were spiked with a bullet and tested. Number of control meat cubes was also five.

\section{Determination of copper and nickel content}

From meat samples, aliquots of $0.5 \mathrm{~g}$ were combined with $5.5 \mathrm{ml}$ nitric acid $(65 \%)$ and $1.5 \mathrm{ml}$ hydrogen peroxide (30\%) and subjected to microwave-assisted digestion (details see Irschik et al. 2013). Meat juice samples (4 ml) were fumed with $10 \mathrm{ml}$ nitric acid $(65 \%)$ and $0.6 \mathrm{ml}$ hydrogen peroxide (30\%), the residue was dissolved in $0.6 \mathrm{ml} \mathrm{HNO}_{3}$ and made up to $20 \mathrm{ml}$ with distilled water (Paulsen et al. 2015a).

Nickel contents were determined by inductively coupled plasma optical emission spectrometry (ICP-OES; PerkinElmer Optima 3000 XL; Perkin-Elmer, USA) using a program validated for meat and offal (Sager 2005). Each run contained two blanks in appropriate dilutions for adequate corrections. Copper was determined by flame AAS (Perkin-Elmer AAnalyst 300) in dilutions of the nitric acid-hydrochloric acid digest (Irschik et al. 2013). Limits of determination were 0.06 and $0.08 \mathrm{mg} / \mathrm{kg}$ (or $\mu \mathrm{g} / \mathrm{ml}$ ) for $\mathrm{Ni}$ and $\mathrm{Cu}$, respectively. 
Estimation of consumer's exposure to copper and nickel via meat from game shot by solid nickel-plated copper bullets

For the estimation of the nickel uptake, we used two approaches. For the first, the amount of $\mathrm{Cu}$ or Ni released from one bullet embedded into meat (juice) during storage or boiling was added to the metal content of a portion of 90 or $250 \mathrm{~g}$ (with average $\mathrm{Cu}$ or $\mathrm{Ni}$ content of the venison control samples; "background level"), and for the second, the median as well as the highest $\mathrm{Cu}$ or $\mathrm{Ni}$ content of a $0.5 \mathrm{~g}$ meat subsample in 2$3 \mathrm{~cm}$ distance from the shot wound was added to the metal content of a meat portion.

\section{Statistical processing of data}

Descriptive statistics were done with MS Excel. Data below the limit of determination (LOD) were set to $1 / 2$ LOD ("middle bound"). $T$ test was used to determine if the release of $\mathrm{Cu}$ and $\mathrm{Ni}$ from bullets into meat juice or meat differed significantly from controls, with $P<0.05$ as level of significance. Significance of differences between copper and nickel contents in tissues near to the shot wound to those of control samples was assessed by Kruskal-Wallis test. In case that the test yielded $P<0.05$, differences between groups were examined by comparing the medians $\pm 1.96 \times$ standard errors of the medians (Lozan and Kausch 1998).

\section{Results and discussion}

\section{Release of $\mathrm{Ni}$ and cu from bullets embedded in meat juice or meat}

Nickel content in meat juice with nickel-free " $\mathrm{T}$ " bullets $(0.2 \pm 0.2 \mu \mathrm{g} \mathrm{Ni} / 10 \mathrm{~g}$ bullet mass) was not significantly different from that of the control $(0.3 \pm 0.0 \mu \mathrm{g} \mathrm{Ni} ; P>0.05)$. Conversely, the Ni-plated " $\mathrm{H}$ "-type released significantly higher amounts of $\mathrm{Ni}(76.5 \pm 10.4 \mu \mathrm{g} / 10 \mathrm{~g}$ bullet; highest single result 92.6). The amount of Ni released from the " $\mathrm{H}$ "type corresponds well to results presented for the Ni-plated Kalahari ("K") bullet (Paulsen et al. 2015a). Significantly, more $\mathrm{Cu}$ was released from the non-plated "T"-type $(215.6 \pm 37.8 \mu \mathrm{g} / 10 \mathrm{~g}$ bullet mass) compared to control $(0.6 \pm 0.0 \mu \mathrm{g})$, also in similar amounts as reported for other $\mathrm{Cu}$-solids (i.e., Barnes TSX; Paulsen et al. 2015a). The $\mathrm{Cu}$ release from "H"-type $(31.1 \pm 10.1 \mu \mathrm{g} / 10 \mathrm{~g}$ bullet mass $)$ was significantly higher than the $\mathrm{Cu}$ content of the control and can be explained by the exposed $\mathrm{Cu}$ surfaces on the cylindrical part of the bullet (where the Ni-cover had been scraped off). Since these were smaller in area than in the "T"-type, comparably lower amounts of $\mathrm{Cu}$ were released.
Metal contents in meat parts adjacent to the embedded bullet followed the same patterns as meat juice with embedded bullets. $\mathrm{Cu}$ contents in meat cubes with embedded " $\mathrm{T}$ "-type bullets were $66.1 \pm 27.9 \mathrm{mg} \mathrm{Cu} / \mathrm{kg}$ (maximum $102.7 \mathrm{mg} / \mathrm{kg}$ ), and thus, significantly higher than in controls $(0.49 \pm 0.14 \mathrm{mg} /$ $\mathrm{kg}$; maximum $0.65 \mathrm{mg} / \mathrm{kg}$ ), whereas the $\mathrm{Cu}$ content in meat with embedded "H"-type bullets was $4.3 \pm 3,1 \mathrm{mg} \mathrm{Cu} / \mathrm{kg}$ (maximum $8.49 \mathrm{mg} / \mathrm{kg}$ ), and not significantly different from controls. Nickel contents in controls and in meat embedded with " $T$ " bullets were $<0.06 \mathrm{mg} / \mathrm{kg}$, and $1.4 \pm 0.8 \mathrm{mg} \mathrm{Ni} / \mathrm{kg}$ (maximum $2.14 \mathrm{mg} / \mathrm{kg}$ ) in meat with embedded " $\mathrm{H}$ " bullets, corresponding to an average of $2.8 \mu \mathrm{g}$ Ni per $2 \mathrm{~g}$ meat adjacent to the bullet.

\section{Contents of cu and $\mathrm{Ni}$ in meat tissue near to the shot wounds}

The median $\mathrm{Cu}$ values from meat near the shot wound (1.6 and $1.9 \mathrm{mg} / \mathrm{kg}$ for " $\mathrm{H}$ " and " $\mathrm{K}$ ") were somewhat higher than in the control (1.3 mg/kg), see Fig. 1. This was, however, of no statistical significance. Single $0.5 \mathrm{~g}$ subsamples contained up to $8.9 \mathrm{mg} \mathrm{Cu} / \mathrm{g}$, which was similar to findings for pure-copper bullets of comparable construction (Irschik et al. 2013). Contents of nickel were below the limit of detection $(0.06 \mathrm{mg} / \mathrm{kg})$ in most controls, with a maximum of $0.29 \mathrm{mg} /$ $\mathrm{kg}$, whereas the medians for meat near " $\mathrm{H}$ " and " $\mathrm{K}$ " shot wounds were 0.1 and $0.3 \mathrm{mg} / \mathrm{kg}$, with corresponding maximum values of 0.2 and $1.8 \mathrm{mg} / \mathrm{kg}$, respectively. Cu contents in control samples are in the range as reported in a recent study on Austrian game meat, with average contents of 1.3 and $1.6 \mathrm{mg} / \mathrm{kg}$ for red and roe deer, respectively (Ertl et al. 2016). These authors also determined Ni contents, and, similar to our study, contents were often below the limit of detection, in this case, $<1 \mu \mathrm{g} / \mathrm{kg}$ (whereas in our study, LOD was $60 \mu \mathrm{g}$ / $\mathrm{kg}$ ). Because non-detectable concentrations have been

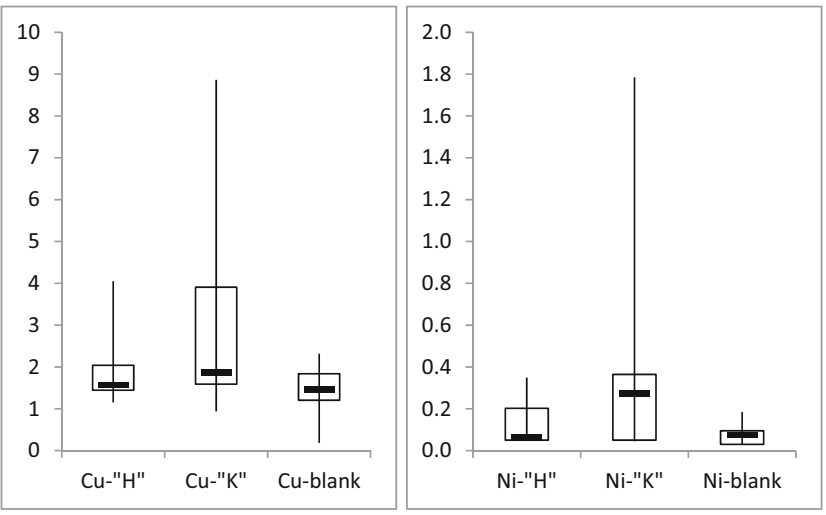

Fig. 1 Box-and-whiskers plot of $\mathrm{Cu}$ and $\mathrm{Ni}$ contents in meat in $2-3 \mathrm{~cm}$ distance from the shot wounds, in milligram per kilogram fresh matter. Thick horizontal bar indicates the median; the box, the first and third quartile. Ranges indicate minimum and maximum metal content per sample. Blank denotes control from distant meat parts (haunch, $n=17$ ); $H$, the " $\mathrm{H}$ " bullet type $(n=20)$; and $K$, the "K" bullet type $(n=13)$ 
assumed to be half of the detection limits, Ertl et al. (2016) report lower average $\mathrm{Ni}$ contents for venison than we do.

Within a sample, the variation between the $0.5 \mathrm{~g}$ subsamples was sometimes considerable. For " $K$ "-type, the ratio for highest to lowest copper content within a sample was $>3: 1$ for $3 / 13$ samples, with a maximum ratio of 18.1:1 and a maximum single result of $34.9 \mathrm{mg} \mathrm{Cu} / \mathrm{kg}$ meat. Ratio of $\mathrm{Ni}$ contents within a sample was $>3: 1$ for $5 / 13$ samples, with a maximum single result of $6.7 \mathrm{mg} \mathrm{Ni} / \mathrm{kg}$ meat. For "H"-type, the ratio for highest to lowest copper content within a sample was $\leq 3: 1$ for all 20 samples, with a maximum ratio of 2.1:1 and a maximum single result of $6.9 \mathrm{mg} \mathrm{Cu} / \mathrm{kg}$ meat. Likewise, ratio of Ni contents within a sample was $>3: 1$ for $8 / 20$ samples, with a maximum single result of $1.4 \mathrm{mg} \mathrm{Ni} / \mathrm{kg}$ meat. In sum, "K"-type subsamples had higher maximum $\mathrm{Ni}$ and $\mathrm{Cu}$ contents, which was considered when meat-borne exposure to $\mathrm{Cu}$ and $\mathrm{Ni}$ was estimated.

\section{Contents of cu and Ni in rumen content}

Median $\mathrm{Cu}$ level in rumen content was $1.7 \mathrm{mg} / \mathrm{kg}$ fresh matter, with a range from 1.4 to $2.3 \mathrm{mg} / \mathrm{kg}$, whereas the median $\mathrm{Ni}$ content was $0.1 \mathrm{mg} / \mathrm{kg}$, with a maximum of $0.3 \mathrm{mg} / \mathrm{kg}$ fresh matter. Since inexpert shots or failures during evisceration can cause contamination of venison with rumen content or faeces, sampling of such contaminated venison could result in biased $\mathrm{Cu}$ and $\mathrm{Ni}$ results. We tried to avoid such bias by sampling only carcasses with cranial-thoracal shot wounds and without visible "green" contamination of the meat.

\section{Estimates for copper and nickel intake via consumption of meat from game}

Estimates for the copper and nickel uptake are shown in Table 1 . In essence, the additional quantity of $\mathrm{Cu}$ would be in the range of 10-20 $\mu \mathrm{g}$ per portion, which is a negligible amount compared to a tolerable daily intake of $35 \mathrm{mg}$ (based on a TDI of $0.5 \mathrm{mg} / \mathrm{kg}$; JECFA 1982). As the surfaces were Ni-plated, it is conceivable that the amounts of copper are lower than those reported for $\mathrm{Cu}$-solids without Ni-plating (Irschik et al. 2013; Paulsen et al. 2015a).

Nickel is known to elicit a variety of adverse health effects (EFSA 2015; Thomas 2016). For oral uptake of Ni, EFSA (2015) derived benchmark dose levels of 1.1 and $2.8 \mu \mathrm{g} / \mathrm{kg}$ body mass for acute (systemic chronic dermatitis) and chronic (foetal loss) adverse health effects. As expected, nickel amounts in median contamination scenarios did not differ from that of control. Based on $70 \mathrm{~kg}$ body mass, the consumption of a $250 \mathrm{~g}$ portion with maximum contamination would contribute to $28 \%$ or $11 \%$ of the benchmark dose levels for acute or chronic adverse health effects of Ni. This calculation includes both natural nickel content as well as bullet-borne nickel contamination. As regards the naturally occurring $\mathrm{Ni}$ content, actual contents might be lower than we calculated ("middle bound" approach), since studies with a lower limit of detection reported lower Ni contents in venison (Ertl et al. 2016).

Maximum concentrations of $\mathrm{Ni}$ in venison attributable to Ni-plated bullets reached $4.3 \%$ of the EFSA benchmark dose for acute and $1.7 \%$ for chronic adverse health effects. To avoid any kind of additional Ni contamination, it should be evaluated if ballistic benefits (e.g. reduced barrel fouling) outweigh any possible negative health effects. Permanent contact to nickel can cause allergic reactions such as skin irritations.

\section{Conclusions}

Nickel-plated copper-solids will release measurable quantities of nickel when stored in meat juice and - in lower amounts-

Table 1 Estimates for the copper and nickel uptake via game meat

\begin{tabular}{lllll}
\hline Contamination scenario & Bullet ${ }^{\mathrm{d}}$ Cu, mg per & \multicolumn{2}{c}{ Ni, $\mu \mathrm{g}$ per portion } \\
portion
\end{tabular}

${ }^{a}$ Example how calculation was made: Median Cu content in controls $(1.5 \mu \mathrm{g} / \mathrm{g}) \times 90(\mathrm{~g})=135 \mu \mathrm{g}$ or $0.13 \mathrm{mg}$ Cu per $90 \mathrm{~g}$ portion; corresponding concentration for Ni was $0.075 \mu \mathrm{g} / \mathrm{g}$, which resulted in $6.75 \mu \mathrm{g}$ Ni per $90 \mathrm{~g}$ portion

${ }^{\mathrm{b}}$ Example, $\mathrm{Ni}$ in $90 \mathrm{~g}$ portion was calculated as $88 \mathrm{~g}$ of meat from control $(0.075 \mu \mathrm{g} / \mathrm{g})=6.6 \mu \mathrm{g}$ plus content in $2 \mathrm{~g}$ meat near bullet $(1.4 \mu \mathrm{g} / \mathrm{g})=2.8 \mu \mathrm{g}$; the sum is $9.4 \mu \mathrm{g}$

${ }^{\mathrm{c}}$ Subsample in 2-3 cm distance from the shot wound ${ }^{\mathrm{d}}$ It was assumed that per portion (90 or $\left.250 \mathrm{~g}\right)$, one bullet was embedded. 
when heated in a meat matrix. In wild game killed with nickelplated bullets, meat in $2-3 \mathrm{~cm}$ distance from the shot wounds had the same median $\mathrm{Cu}$ and $\mathrm{Ni}$ contents than meat from distant region (haunch). Only maximum contamination scenarios did increase $\mathrm{Cu}$ and $\mathrm{Ni}$ contents for ca. 20 and $3.3 \mu \mathrm{g}$, respectively. Whereas the increase in $\mathrm{Cu}$ contents is of no concern, the known adverse effects of Ni should restrict its use, especially as at least for some bullet types, equivalent non-nickel-plated bullets made of copper are available. Higher Ni levels in venison could be a food safety concern, but more likely in terms of contamination-which could render meat unfit for consumption (EC 2002) — rather than posing a health hazard.

Data were obtained by testing the entire bullets and not fragments; thus, the actual quantities of $\mathrm{Ni}$ deposited in tissues could be lower, when smaller fragments with correspondingly smaller outer surfaces come in contact with meat.

Acknowledgements Open access funding provided by University of Veterinary Medicine Vienna. Special thanks are due to Dr. Hans Mattes and Marian Riedler both "Österreichische Bundesforste AG, Forstbetrieb Voralpen", for providing meat from animals. Wild game had been killed during regular hunts.

\section{Compliance with ethical standards}

Conflict of interest The authors declare that they have no conflict of interest.

Funding This study received no funding.

Open Access This article is distributed under the terms of the Creative Commons Attribution 4.0 International License (http:// creativecommons.org/licenses/by/4.0/), which permits unrestricted use, distribution, and reproduction in any medium, provided you give appropriate credit to the original author(s) and the source, provide a link to the Creative Commons license, and indicate if changes were made.

\section{References}

Bundesinstitut für Risikobewertung BfR (2010) Bleibelastung von Wildbret durch Verwendung von Bleimunition bei der Jagd. Stellungnahme Nr. 040/ 2011 des BfR vom 3. Dezember 2010. http:/www.bfr.bund.de/cm/343/bleibelastung-von-wildbret-durchverwendung-von-bleimunitionbei-der-jagd.pdf. Accessed 12 Feb 2017

EC (2002) Regulation (EC) No 178/2002 of the European Parliament and of the Council of 28 January 2002 laying down the general principles and requirements of food law, establishing the European Food Safety Authority and laying down procedures in matters of food safety. OJ L31:1-24. http://eur-lex.europa.eu/LexUriServ/ LexUriServ.do?uri=OJ:L:2002:031:0001:0024:en:PDF. Accessed $12 \mathrm{Feb} 2017$

EFSA (2015) EFSA panel on contaminants in the food chain (CONTAM); scientific opinion on the risks to public health related to the presence of nickel in food and drinking water. EFSA J 13(2): 146. doi:10.2903/j.efsa.2015.4002

Ertl K, Kitzer R, Goessler W (2016) Elemental composition of game meat from Austria. Food Addit Contam B 9:120-126

Felsman MZ, Szarek J, Felsmann M, Gulda D (2016) Lead in game bird meat as a risk to public health: new aspects in the light of physical phenomena generated by a projectile. J Elem 21 . doi:10.5601/jelem. 2015.20.3.989

Gremse F, Krone O, Thamm M, Kiessling F, Tolba RH, Rieger S, Gremse C (2014) Performance of lead-free versus lead-based hunting ammunition in ballistic soap. PLoS One 9(7):e102015

Irschik I, Bauer F, Sager M, Paulsen P (2013) Copper residues in meat from wild artiodactyls hunted with two types of rifle bullets manufactured from copper. Eur J Wildl Res 59:129-136

Irschik I, Wanek C, Bauer F, Sager M, Paulsen P (2014) Composition of bullets used for hunting and food safety considerations. In: Paulsen P, Bauer A, Smulders FJM (eds) Trends in game meat hygiene: from forest to fork. Wageningen Academic Publishers, Wageningen, pp 363-370 ISBN: 978-90-8686-238-2

JECFA (1982) http://apps.who.int/food-additives-contaminants-jecfadatabase/chemical.aspx?chemID=2824. Accessed 16 Feb 2017

Kanstrup N, Balsby TJS, Thomas VG (2016) Efficacy of non-lead rifle ammunition for hunting in Denmark. Eur J Wildl Res 62:333-340

Lozan JL, Kausch A (1998) Angewandte Statistik für Naturwissenschaftler, 2nd edn. Blackwell, Wien, p 44, pp 134-137

Nadjafzadeh M, Hofer H, Krone O (2015) Lead exposure and food processing in white-tailed eagles and other scavengers: an experimental approach to simulate lead uptake at shot mammalian carcasses. Eur J Wildl Res 61:763-774

Paulsen P, Bauer F, Sager M, Schuhmann-Irschik I (2015a) Model studies for the release of metals from embedded rifle bullet fragments during simulated meat storage and food ingestion. Eur J Wildl Res 61:629633

Paulsen P, Sager M, Bauer F, Schuhmann-Irschik I (2015b) Pilot study on metal contents in meat portions from wild game killed by "leadfree" rifle bullets. J Food Saf Food Qual 66:128-131

Paulsen P, Schuhmann-Irschik I, Sager M, Bauer F (2017) Assessment of primary oxidation products in venison with embedded copper particles subjected to culinary processing. In: Paulsen P, Bauer A, FJM S (eds) Game meat hygiene: food safety and security. Wageningen Academic Publishers, Wageningen, pp 213-219 ISBN: 978-908686-295-5

Sager M (2005) Multi-Elementbestimmung in Fleisch, Leber und Nieren. Ernährung/Nutrition 29:151-156

Schuhmann-Irschik I, Sager M, Paulsen P, Tichy A, Bauer F (2015) Release of copper from embedded solid copper bullets into muscle and fat tissues of fallow deer (Dama dama), roe deer (Capreolus capreolus), and wild boar (Sus scrofa) and effect of copper content on oxidative stability of heat-processed meat. Meat Sci 108:21-27

Thomas VG (2013) Lead-free hunting rifle ammunition: product availability, price, effectiveness, and role in global wildlife conservation. Ambio 42(6):737-745

Thomas VG (2016) Elemental tungsten, tungsten-nickel alloys and shotgun ammunition: resolving issues of their relative toxicity. Eur $\mathrm{J}$ Wildl Res 62:1-9

Thomas VG, Gremse C, Kanstrup N (2016) Non-lead rifle hunting ammunition: issues of availability and performance in Europe. Eur J Wildl Res 62:633-641

Trinogga A, Fritsch G, Hofer H, Krone O (2013) Are lead-free hunting rifle bullets as effective at killing wildlife as conventional lead bullets? A comparison based on wound size and morphology. Sci Total Environ 443:226-233 